\title{
Association between body condition score and live weight in pasture-based Holstein-Friesian dairy cows
}

\author{
Donagh P Berry ${ }^{1 *}$, Kevin A Macdonald ${ }^{2}$, John W Penno ${ }^{2}+$ and John R Roche ${ }^{2}$ \\ ${ }^{1}$ Teagasc Moorepark, Fermoy, Co. Cork, Ireland \\ ${ }^{2}$ Dexcel, Private Bag 3221, Hamilton, New Zealand
}

Received 23 March 2006 and accepted for publication 17 May 2006

\begin{abstract}
The objective was to quantify the strength of the relationship between body condition score (BCS) and live weight (LW) in pasture-based Holstein-Friesian dairy cattle, and to determine the kg LW per unit BCS. A total of 26021 test-day records with information on both BCS (1-10 scale, where 1 is emaciated and 10 is obese) and LW across 1110 lactations from one research farm were used in the analysis. Correlation and regression analyses were used to determine the degree of association between BCS and LW in different parities, stages of the inter-calving interval and years. Correlations between BCS and LW were relatively consistent, with the mean correlation between BCS and LW across all data of 0.55 implying that differences in BCS explain approximately $30 \%$ of the variation in LW. Significantly different regressions of LW on BCS were present within stage of inter-calving interval by parity subclasses. Excluding calving, LW per unit BCS varied from $17 \mathrm{~kg}$ (early to mid lactation in parity 1 ) to $36 \mathrm{~kg}$ (early lactation in parity 4 and 5). However, LW per unit BCS was greatest at calving varying from $44 \mathrm{~kg}$ in first parity animals to $62 \mathrm{~kg}$ in second parity animals. On average, $1 \mathrm{BCS}$ unit equated to $31 \mathrm{~kg} \mathrm{LW}$ across all data.
\end{abstract}

Keywords: Body condition score, live weight, regression, dairy cattle.

Body condition scoring subjectively assesses the body energy reserves of an animal. Several reports document associations between body condition score (BCS) and fertility (Gillund et al. 2001; Buckley et al. 2003) and health (Roche \& Berry, 2006). Despite the reported moderate to high inter- and intra-classifier repeatability estimates in experienced assessors (Bowden, 1982; Ferguson et al. 1994) the subjective nature of condition scoring makes it difficult for inexperienced herd managers to make use of management recommendations. Additionally, the automation of body condition scoring has to date been unsuccessful. Nonetheless, automatic daily weighing of cows is commercially available and facilitates the monitoring of daily live weight (LW) change as well as LW change during key periods of lactation which have been associated with fertility (Buckley et al. 2003). However, the relationship between BCS and LW is impacted by factors such as parity, stage of lactation, gut fill, frame size, gestation and breed (Grainger et al. 1982; Enevoldsen \&

*For correspondence; e-mail: donagh.berry@teagasc.ie tPresent address: Synlait, RD13, Te Pirita Rd, Rakaia, New Zealand
Kristensen, 1997; Stockdale, 1999). Therefore it is of interest to quantify the relationship between BCS and LW at different ages and stages of lactation with or without accounting for the weight of the fetus and associated membranes and fluids.

Previous international studies indicate, as one would expect, that the genes influencing BCS and LW are either closely linked or have pleiotrophic effects on each other (i.e. genes that affect LW also affect BCS). Results indicate moderate $(0 \cdot 34-0.55)$ phenotypic (Enevoldsen \& Kristensen, 1997; Berry et al. 2002) and genetic (Berry et al. 2002) correlations between BCS and LW in dairy cattle. Berry et al. (2002) also reported variations in the genetic correlation between BCS and LW at different stages of lactation, suggesting that different conversion equations may be required for different stages of lactation. Although the gross relationship between LW and BCS is both logical and previously reported (Enevoldsen \& Kristensen, 1997; Berry et al. 2002) to date very little is published on the effect of parity or stage of lactation on this relationship, or on the amount of LW associated with incremental changes in BCS in grazing dairy cows.

The objective of the present study was to estimate the strength of the association between BCS and LW, and to 
quantify the LW change per incremental change in BCS across different parities and stages of the inter-calving interval in pasture-based Holstein-Friesian dairy cows.

\section{Materials and Methods}

\section{Dataset and animals}

Data on cow number, year of birth, parity number and associated calving dates were extracted from the Dexcel research database on 1110 calvings from 446 HolsteinFriesian dairy cows at No. 2 dairy research farm for the years 1995-2000, inclusive. No. 2 dairy farm was used for systems-based research, and the period in question incorporated 18 research treatments undertaken over multiple lactations (54 different herd $\times$ year farmlets) comparing systems that optimized the use of nitrogen fertilizer and supplementary feeds, and research to determine the most profitable stocking rate for grazing dairy systems. Mean herd size across the years was 188 cows.

The system of milk production was seasonal, with approximately $50 \%$ of cows calving in 2 weeks, $40 \%$ calving in the next 4 weeks and the remaining cows calving during weeks 7 and 8 . Grazing regimens varied very little between treatments. In general, herbage was grazed when between $2 \cdot 0$ and 3.0 leaves had regrown on the majority of perennial ryegrass tillers (approximately $2500 \mathrm{~kg} \mathrm{DM} / \mathrm{ha}$ in spring, $4000 \mathrm{~kg} \mathrm{DM} / \mathrm{ha}$ in summer and $3000 \mathrm{~kg} \mathrm{DM} / \mathrm{ha}$ in autumn and winter - all measurements are to ground level). Postgrazing residuals approximated $40 \mathrm{~mm}$ during winter and spring and $60 \mathrm{~mm}$ during summer and autumn. Detailed accounts of management decision rules are provided by Macdonald \& Penno (1998).

Throughout the period investigated, the precalving diet would have largely consisted of fresh pasture (predominantly perennial ryegrass, Lolium perenne L.) and pasture silage during periods of insufficient fresh pasture. Soils were fertile silt loams (Aquic Dystandepts, Haplic Andaquepts, Umbric Vitrandepts) and peaty silt loams (Humic Haptorthod). The farm received annual 'maintenance' dressings of $54 \mathrm{~kg} \mathrm{P} / \mathrm{ha}$ and $55 \mathrm{~kg} \mathrm{~S} / \mathrm{ha}$ as Single Superphosphate $\left(\mathrm{Ca}\left(\mathrm{H}_{2} \mathrm{PO}_{4}\right)_{2} \cdot \mathrm{CaSO}_{4}\right)$ in November, and $50 \mathrm{~kg} \mathrm{~K} / \mathrm{ha}$ as Muriate of Potash $(\mathrm{KCl})$ in March. Across the years being studied, the annual nitrogen application rate varied from $172 \mathrm{~kg} / \mathrm{ha}$ to $286 \mathrm{~kg} / \mathrm{ha}$.

\section{Measurements}

BCS and LW were recorded within 1 week of calving, and every 2 weeks during the inter-calving period at approximately 9 a.m. BCS was evaluated by two experienced assessors over the 6 years; the anatomy considered in the BCS assessment included the thoracic and vertebral region of the spinal column (chine, loin and rump), the ribs, the spinous processes (loin), the tuber sacrale (hip or hook bones), the tuber ischii (pin bones), the anterior coccygeal vertebrae (tail head) and the thigh region. Assessments were on a 10-point scale, where 1 is emaciated and 10 is obese (Roche et al. 2004). All BCS and LW records including those for the 8-week precalving period were retained. In total, 26021 test-day records with information on both BCS and LW were available for inclusion in the analysis.

In a series of separate analyses, LW was adjusted for the weight of the fetus at day $g$ of gestation using the formula of Bruce et al. (1984) assuming a calf weight of $40 \mathrm{~kg}$ :

$\log _{10}($ Fetus weight $)=2 \cdot 932-3 \cdot 347 \mathrm{e}^{-0.00406 * \mathrm{~g}}$

Conception date was estimated using the subsequent calving date less a gestation length of $282 \mathrm{~d}$. Not all animals had subsequent calving dates. Because of the initiation of a new study on the No. 2 dairy research farm in 2001, which included only primiparous heifers, no subsequent calving dates were available for animals in the final year of the present dataset.

\section{Data editing and analysis}

Parity was recoded as 1, 2, 3, 4, 5 and $6+$. Fortnight of the year at calving was defined as the fortnight of the calendar year when an animal calved, with fortnight 1 beginning on 1 January each year. The inter-calving interval was separated into five stages, $-64-0 \mathrm{~d}$ relative to calving, 10-50 d post-calving, 51-100 d post-calving, 101-200 d post-calving and 201-300 d post-calving. Precalving records were not available on primiparous cows. BCS and LW at calving were determined per lactation as the first record post-calving, but within $7 \mathrm{~d}$ post-calving. Lactation records were also divided into quartiles based on LW at calving. Quartile thresholds were 418, 468 and $522 \mathrm{~kg}$.

Pearson correlations were estimated between BCS and LW across different parities, stages of the inter-calving interval and years. Because some of the Pearson correlations deviated considerably from zero the sampling distribution of the correlations was likely to be skewed. For this reason the Fischer's $r$ to $Z$ transformations were performed to derive the confidence intervals for each correlation and the significance, or lack thereof, of a difference between two correlations as well as among all correlations within parity, stage of the inter-calving period or year investigated.

Mixed model methodology in PROC MIXED (SAS, 2006) was used to determine the LW change associated with one unit difference in BCS. Cow was included as a random effect in the model. The Akaike information criterion was minimized when an unstructured covariance matrix was assumed among records within cow. Class variables tested in the model were year of calving, fortnight of the year at calving, parity, stage of the inter-calving interval as well as interactions between these variables. 
Table 1. Correlationst between body condition score and live weight measured in different parities, stages of the inter-calving interval, and years

\begin{tabular}{|c|c|c|c|}
\hline Class & Parity $\ddagger$ & Stage§ & Year $\uparrow$ \\
\hline 1 & $0 \cdot 49^{a}$ & $0 \cdot 58^{\mathrm{ab}}$ & $0 \cdot 52^{b}$ \\
\hline 2 & $0.63^{c}$ & $0 \cdot 54^{b c}$ & $0 \cdot 46^{\mathrm{a}}$ \\
\hline 3 & $0 \cdot 58^{b}$ & $0 \cdot 59^{a}$ & $0 \cdot 54^{\mathrm{bc}}$ \\
\hline 4 & $0 \cdot 57^{b}$ & $0.56^{\text {bd }}$ & $0.56^{c}$ \\
\hline 5 & $0 \cdot 52^{\mathrm{a}}$ & $0 \cdot 50^{c}$ & $0.64^{d}$ \\
\hline 6 & $0 \cdot 51^{\mathrm{a}}$ & $0 \cdot 54^{d}$ & $0.60^{\mathrm{e}}$ \\
\hline
\end{tabular}

†Values within a column with different superscripts differ significantly $(P<0 \cdot 05)$

₹Class 1 to 6 refers to parity 1 to 6 , respectively

§Class 1 to 6 refer to stages $-64-0 \mathrm{~d}$ relative to calving, calving, $10-50 \mathrm{~d}$ post-calving, 51-100 d post-calving, 101-200 d post-calving and 201$300 \mathrm{~d}$ post-calving, respectively

IClass 1 to 6 refer to the years 1995-2000, respectively
Table 2. Regression coefficients (SE in parenthesis) representing live weight $(\mathrm{kg})$ per unit body condition score (1-10 scale, where 1 is emaciated and 10 obese) within parity across stages of the inter-calving interval and at calving, and within stage across parities

$\begin{array}{lll}\text { Class } & \text { Parity } † & \text { Stage } \neq \\ 1 & 20(0 \cdot 7) & 34(0 \cdot 7) \\ 2 & 29(0 \cdot 6) & 52(2 \cdot 1) \\ 3 & 32(0 \cdot 6) & 33(0 \cdot 6) \\ 4 & 34(0 \cdot 6) & 30(0 \cdot 6) \\ 5 & 35(0 \cdot 7) & 30(0 \cdot 5) \\ 6 & 33(0 \cdot 5) & 29(0 \cdot 4)\end{array}$

† Class 1 to 6 refers to parity 1 to 6 , respectively ₹Class 1 to 6 refers to stages $-64-0$ d relative to calving, calving, $10-50 \mathrm{~d}$ post-calving, 51-100 d post-calving, 101-200 d post-calving and 201$300 \mathrm{~d}$ post-calving, respectively

Table 3. Regression coefficients (SE in parenthesis) representing live weight (kg) per unit body condition score (1-10 scale, where 1 is emaciated and 10 obese) across parity by stage of the inter-calving interval and parity by calving

\begin{tabular}{|c|c|c|c|c|c|c|}
\hline \multirow[b]{2}{*}{ Parity } & \multicolumn{5}{|c|}{ Stage of the inter-calving period } & \multirow[b]{2}{*}{$\begin{array}{l}201-300 \mathrm{~d} \\
\text { post-calving }\end{array}$} \\
\hline & $\begin{array}{l}-64-0 \mathrm{~d} \\
\text { pre-calving }\end{array}$ & Calving & $\begin{array}{l}10-50 \mathrm{~d} \\
\text { post-calving }\end{array}$ & $\begin{array}{l}51-100 \mathrm{~d} \\
\text { post-calving }\end{array}$ & $\begin{array}{l}101-200 \mathrm{~d} \\
\text { post-calving }\end{array}$ & \\
\hline 1 & & $44(5 \cdot 1)$ & $21(0 \cdot 9)$ & $17(0 \cdot 9)$ & $20(0 \cdot 8)$ & $23(0 \cdot 7)$ \\
\hline 2 & $29(0 \cdot 9)$ & $62(4 \cdot 6)$ & $33(0 \cdot 8)$ & $29(0 \cdot 9)$ & $29(0 \cdot 7)$ & $31(0 \cdot 7)$ \\
\hline 3 & $33(0 \cdot 9)$ & $58(5 \cdot 1)$ & $35(0 \cdot 8)$ & $31(0 \cdot 9)$ & $32(0 \cdot 7)$ & $32(0 \cdot 7)$ \\
\hline 4 & $34(0 \cdot 9)$ & $51(5 \cdot 4)$ & $36(0 \cdot 9)$ & $33(0 \cdot 9)$ & $33(0 \cdot 7)$ & $34(0 \cdot 7)$ \\
\hline 5 & $35(0 \cdot 9)$ & $55(4 \cdot 9)$ & $36(0 \cdot 9)$ & $33(0 \cdot 9)$ & $33(0 \cdot 8)$ & $32(0 \cdot 8)$ \\
\hline 6 & $33(0 \cdot 8)$ & $46(4 \cdot 2)$ & $34(0 \cdot 8)$ & $30(0 \cdot 8)$ & $31(0 \cdot 7)$ & $30(0 \cdot 6)$ \\
\hline
\end{tabular}

BCS was treated as a continuous variable with higher order polynomials also tested for significance in the model. Significance was declared at $P<0.05$ based on the F-test.

\section{Results and Discussion}

Mean (SD) for BCS pre-calving, at calving, 10-50 d postcalving, 51-100 d post-calving, 101-200 d post-calving and 201-300 d post-calving was $4 \cdot 7(0 \cdot 64), 4 \cdot 8(0 \cdot 65), 4 \cdot 2$ $(0 \cdot 67), 4 \cdot 3(0 \cdot 58), 4 \cdot 4(0.55)$ and $4 \cdot 2(0 \cdot 65)$ BCS units, respectively; corresponding values for LW were $520(57 \cdot 6)$, $469(73 \cdot 5) ; 426(64 \cdot 1), 444(62 \cdot 3), 465(59 \cdot 4)$ and 481 $(55 \cdot 2) \mathrm{kg}$, respectively.

Table 1 summarizes the correlations between BCS and LW in different parities, stages of the inter-calving interval, and years. Although correlations were similar, varying from 0.46 to 0.64 , correlations within each stage of the inter-calving interval, parity or year were significantly different from each other. The correlation was lowest in first parity animals, highest in second parity animals and declined thereafter with parity. Correlations between LW and BCS in early lactation were different $(P<0 \cdot 05)$ from the correlations in late lactation. Adjustment of LW for fetus and associated membranes and fluids did not significantly affect the correlations between BCS and LW pre-calving or in the latter stages of lactation. The correlation across the entire dataset was 0.55 indicating that BCS explained $30 \%$ of the variation in LW. The range of correlations observed in the present study is consistent with previous correlation estimates between BCS and LW in systems using 5-point BCS systems (Enevoldsen \& Kristensen, 1997; Berry et al. 2002). The consistency between these relationships across international scoring systems supports the recently reported relationship across systems of BCS used internationally (Roche et al. 2004).

The regression coefficient across all data, excluding the first $10 \mathrm{~d}$ post-calving, was $31 \mathrm{~kg}(\mathrm{SE}=0.3 \mathrm{~kg}$ ), implying a change of $31 \mathrm{~kg}$ LW for every unit change in BCS. Higher order polynomials of LW on BCS were not significant. The linear coefficient is consistent with the $70-77 \mathrm{~kg}$ LW per BCS unit reported by Berry et al. (2002), when the regression equation generated by Roche et al. (2004; 5 -point system $=0 \cdot 81+0 \cdot 4 \times 10$-point system) is used to convert between the different condition scoring systems (77.5 kg/BCS unit). This is despite an expected difference in frame size between cows on both studies. Berry et al. (2005) reported significantly greater height and girth in mature cows of North American ancestry compared with 
mature cows of New Zealand ancestry. Cows in the present study were of New Zealand origin while those on the study of Berry et al. (2002) had a mean of $48 \%$ North American Holstein-Friesian genes. However, there was a significant $(P<0 \cdot 001)$ interaction between LW per unit BCS and quartile of LW at calving. Regression coefficients (SE in parenthesis) were $27.5(0.33), 28.8(0 \cdot 31), 30 \cdot 1$ $(0 \cdot 30)$ and $32 \cdot 2(0 \cdot 30) \mathrm{kg} / \mathrm{BCS}$ unit for the lightest to heaviest quartile, respectively. This indicates that LW per unit BCS increases with the LW of the animal at calving, which is an indicator of body size.

Nonetheless, the amount of LW associated with each unit of BCS in both the current study and that of Berry et al. (2002) is much greater than the range reported by Enevoldsen \& Kristensen $(1997$; 32-47 kg LW/BCS unit on a 1-5 BCS scale), Jaurena et al. (2005; 21-35 kg LW/BCS unit on a 1-5 BCS scale) and Grainger et al. $(1982 ; 42 \mathrm{~kg}$ LW/BCS unit on a 1-8 BCS scale). A possible reason for this inconsistency was the large proportion of primiparous cows $(37 \%)$ in the study of Enevoldsen \& Kristensen (1997), reducing the kg LW per BCS unit. Regression coefficients of LW on BCS derived for each parity across stages, or for each stage across parity are outlined in Table 2. Therefore the large proportion of primiparous cows in the study of Enevoldsen \& Kristensen (1997) would be expected to result in a reduced LW per unit BCS compared with those reported either here or by Berry et al. (2002). The regression coefficient of $20 \mathrm{~kg}$ per unit BCS in primiparous cows on the BCS scale of 1-10 conforms to $50 \mathrm{~kg}$ on the Irish scale of 1-5 using the conversion equation of Roche et al. (2006). Although Jaurena et al. (2005) only included multiparous animals, these animals were fed total mixed rations which may also affect the association between BCS and LW because of gut fill.

Another possible reason for the inconsistency is the fact that Enevoldsen \& Kristensen (1997) and Jaurena et al. (2005) did not investigate the presence of an interaction between stage of lactation and the regression of LW on BCS. Differences in means and variations in BCS and LW between studies may also impact on the associations. Our results identify an interaction, suggesting a change in the relationship between LW and BCS across time. Across parities, LW per unit BCS varied between $29 \mathrm{~kg}$ (late lactation) and $52 \mathrm{~kg}$ (at calving). Ignoring BCS at calving the difference in the regression coefficients across time are small and are probably due to differences in internal stores of body fat, which is not adequately assessed by palpating external body parts, as well as the effect of gut fill and gestation (Andrew et al. 1994). Nonetheless, adjustment for the fetus and associated pregnancy tissues and fluids did not considerably affect the regression coefficients which decreased by a maximum of $3 \mathrm{~kg}$ (pre-calving stage).

The significant interaction between parity, stage of lactation and the regression of LW on BCS was quadratic $(P<0.05)$ but a graphical examination of the quadratic regression revealed only minimal deviation from a linear association. Regression coefficients of LW on BCS, when BCS was included in an interaction with parity and stage of lactation, as well as a separate analysis with calving LW as the dependent variable are summarized in Table 3. Because the quadratic term did not appear biologically important, only regression coefficients with a linear term included in the model are reported. Excluding calving, LW per unit BCS varied from $17 \mathrm{~kg}$ (early to mid lactation in parity one) to $36 \mathrm{~kg}$ (early lactation in parity 4 and 5). However, LW per unit BCS was greatest at calving varying from $44 \mathrm{~kg}$ in first parity animals to $62 \mathrm{~kg}$ in second parity animals.

In conclusion, the results indicate a moderate correlation between BCS and LW in pasture-based dairy cows, with BCS explaining on average $30 \%$ of the variation in LW. Mixed model analysis revealed that one BCS unit represents $31 \mathrm{~kg}$ LW on average, but this varies from 20 to $35 \mathrm{~kg}$ with parity. Nonetheless, the effect of gut fill on an individual cow basis on any particular day will also impact on this association.

The authors acknowledge the assistance of J Lee, J Lancaster and $\mathrm{C}$ Leydon-Davis in compiling the database.

\section{References}

Andrew SM, Waldo DR \& Erdman RA 1994 Direct analysis of body composition of dairy cows at three physiological stages. Journal of Dairy Science 77 3022-3033

Berry DP, Buckley F, Dillon P, Evans RD, Rath M \& Veerkamp RF 2002 Genetic parameters for level and change of body condition score and body weight in dairy cows. Journal of Dairy Science 85 2030-2039

Berry DP, Horan B \& Dillon P 2005 Comparison of growth curves of three strains of female dairy cattle. Animal Science 80 151-160

Bowden V 1982 Type classification in dairy cattle: a review. Animal Breeding Abstracts 50 147-162

Bruce JM, Broadbent PJ \& Topps JH 1984 A model of the energy system of lactating and pregnant cows. Animal Production 38 351-362

Buckley F, O'Sullivan K, Mee JF, Evans RD \& Dillon P 2003 Relationships among milk yield, body condition, cow weight, and reproduction in spring-calving Holstein-Friesians. Journal of Dairy Science $\mathbf{8 6}$ 2308-2319

Enevoldsen C \& Kristensen T 1997 Estimation of body weight from body size measurements and body condition scores in dairy cows. Journal of Dairy Science $\mathbf{8 0} 1988-1995$

Ferguson JD, Galligan DT \& Thompson N 1994 Principal descriptors of body condition score in Holstein cows. Journal of Dairy Science 77 2695-2703

Gillund P, Reksen O, Gröhn YT \& Karlberg K 2001 Body condition related to ketosis and reproductive performance in Norwegian dairy cows. Journal of Dairy Science 84 1390-1396

Grainger C, Wilhems GD \& McGowan A 1982 Effect of body condition at calving and level of feeding in early lactation on milk production of dairy cows. Australian Journal of Experimental Agriculture and Animal Husbandry 22 9-17

Jaurena G, Moorby, JM, Fisher WJ \& Cantet R 2005 Association of body weight, loin Longissimus dorsi and backfat with body condition score in dry and lactating Holstein dairy cows. Animal Science 80 219-223

Macdonald KA \& Penno JW 1998 Management decision rules to optimise milksolids production on dairy farms. Proceedings of the New Zealand Society of Animal Production 58 132-135 
Roche JR \& Berry DP 2006 Periparturient climatic, animal and management factors influencing the incidence of milk fever in grazing systems. Journal of Dairy Science 89 2775-2783

Roche JR, Dillon PG, Stockdale CR, Baumgard LH \& VanBaale MJ 2004 Relationships among international body condition scoring systems. Journal of Dairy Science 87 3076-3079
SAS 2006 User's Guide Version 9.1: Statistics. SAS Institute, Cary NC, USA

Stockdale CR 1999 Effect of length of the period of supplementation with concentrates on pasture intake and performance of grazing dairy cows. Australian Journal of Experimental Agriculture 39 803-809 